\title{
PENGARUH MOTIVASI KERJA KEPUASAN KERJA DAN KOMITMEN ORGANISASI TERHADAP KINERJA KARYAWAN PADA PT. FEDERAL INTERNASIONAL FINANCE CABANG MAROS
}

\author{
Dicky Zulkarnain Rona Gah \\ Program Pascasarjana Universitas Muslim Indonesia \\ Email : Dickydzulkarnain23@gmail.com
}

\begin{abstract}
ABSTRAK
DICKY ZULKARNAIN RONA GAH. Pengaruh Motivasi Kerja, Kepuasan Kerja dan Komitmen Organisasi terhadap Kinerja Karyawan pada PT. Federal Internasional Finance Cabang Maros.
\end{abstract}

Penelitian ini bertujuan untuk menganalisis pengaruh motivasi kerja, kepuasan kerja dan komitmen organisasi terhadap kinerja karyawan pada PT. Federal Internasional Finance

Penelitian ini dilaksanakan di PT.FIF Cabang Maros, dengan populasi dan sampel seluruh karyawan yang berjumlah 55 orang. Data dikumpulkan melalui penyebaran kuesioner dan dokumentasi. Data dianalisis melalui Uji Validitas, Reliabilitas, Uji Asumsi Klasik, Analisis Regresi Linear Berganda, dan Koefisien Determinasi (R2), dengan mengunakan aplikasi SPSS.

Hasil penelitian menunjukan bahwa secara parsial komitmen organisasi berpengaruh positf dan tidak signifikan terhadap kinerja karyawan, sedangkan motivasi kerja dan kepuasan kerja berpengaruh positif dan signifikan terhadap kinerja karyawan. Variabel kepuasan kerja dominan berpengaruh terhadap kinerja karyawan pada PT. Federal Internasional Finance Cabang Maros.

Kata Kunci : Motivasi kerja, Kepuasan kerja, Komitmen organisasi, Kinerja

\begin{abstract}
DICKY ZULKARNAIN RONA GAH. The Influence of Job Motivation, Job Satisfaction and Organization Commitment toward Employee's Performance at PT. Federal International Finance, Maros.

This research aims to analyze the influence of job motivation, job satisfaction and organization commitment toward employee's performance at PT. Federal International Finance.
\end{abstract}


This research was conducted at PT.FIF Maros, by population and samples are fifty five (55), the total number of employees. Data were collected by using questionnaire and documentation. The data were analyzed through Validity and Reliability Test, Classical Assumption Test, Multiple Linear Regression, and Coefficient Determination (R2), by using SPSS Application.

The results showed that as partial, organization commitment was not significant influenced the employee's performance, while job motivation and satisfaction have a positive and significant influence to the employee's performance. Job satisfaction were influenced dominant to employee's performance at PT. Federal International Finance Maros

Keyword: Job Motivation, Job Satisfaction, Organization Commitment, Performance.

\section{PENDAHULUAN}

Peran manusia didalam perusahaan merupakan modal besar dimana kinerja karyawan sangat menentukan maju mundurnya suatu organisasi. Sehingga diperlukan pembinaan dan pengembangan dalam mendorong peningkatan kinerja karyawan secara efektif demi kelancaran proses kegiatan dalam suatu perusahaan yang akan datang. Patut disadari begitu pentingnya peranan manusia seperti diuraikan di atas, maka setiap perilaku karyawan dalam suatu perusahaan harus diarahkan. Untuk itu sudah seharusnya kinerja karyawan diperhatikan secara layak dan adil, sehingga mereka dapat melaksanakan tugas dengan sungguh - sungguh dan penuh dengan tanggung jawab. Mangkunegara (2005)

Dunia bisnis sekarang dituntut menciptakan kinerja karyawan yang tinggi untuk pengembangan perusahaan. Perusahaan harus mampu membangun dan meningkatkan kinerja didalam lingkungannya. Keberhasilan perusahaan tersebut dipengaruhi oleh beberapa faktor, salah satu faktor penting adalah sumber daya manusia, karena sumber daya manusia merupakan pelaku dari keseluruhan tingkat perencanaan sampai dengan evaluasi yang mampu memanfaatkan sumber daya lainnya yang dimiliki oleh organisasi atau perusahaan.

Keberadaan sumber daya manusia didalam suatu perusahaan memegang peranan sangat penting. Tenaga kerja memiliki potensi yang besar untuk menjalankan aktivitas perusahaan. Potensi setiap sumber daya manusia yang ada dalam perusahaan harus dapat dimanfaatkan dengan sebaik-baiknya sehingga mampu memberikan output optimal. Tercapainya tujuan perusahaan tidak hanya tergantung pada peralatan modern, sarana dan prasarana yang lengkap, tetapi justru lebih tergantung pada manusia yang melaksanakan pekerjaan tersebut. Keberhasilan suatu organisasi sangat dipengaruhi oleh kinerja individu karyawannya. Setiap organisasi maupun perusahaan akan selalu berusaha untuk meningkatkan kinerja karyawan, dengan harapan apa yang menjadi tujuan perusahaan akan tercapai.

Suatu organisasi baik perusahaan maupun instansi dalam melakukan aktivitasnya 
sudah tentu memerlukan sumber daya manusia yang mendukung usaha pencapaian tujuan yang telah ditetapkan oleh organisasi. Bagaimanapun lengkap dan canggihnya sumbersumber daya non-manusia yang dimiliki oleh suatu perusahaan, tidaklah menjadi jaminan bagi perusahaan tersebut untuk mencapai suatu keberhasilan. Motivasi kerja karyawan merupakan salah satu faktor yang dapat menentukan keberhasilan suatu perusahaan dalam mencapai tujuan, dimana hal tersebut menjadi perhatian oleh pihak manajemen.

Salah satu dari teori motivasi yang dikemukakan dan dibahas adalah model herarki kebutuhan yang diusulkan oleh Abraham Maslow (dalam Gibson, et al 2001). Tingkat terendah adalah kebutuhan fisiologi dan tingkat tertinggi adalah aktualisasi diri. Maslow membagi kebutuhan manusia atas :

1. Fisiologis : Makanan, minuman, tempat tingal dan sembuh dari rasa sakit.

2. Keamanan dan keselamatan : Kebutuhan untuk kemerdekaan dari ancaman, yaitu keamanan dari kejadian atau lingkungan yang mengancam.

3. Rasa memiliki, social dan kasih sayang : Kebutuhan atas persahabatan, berkelompok, interaksi dan kasih sayang.

4. Penghargaan (esteem) : Kebutuhan atas harga diri (self-esteem) dan penghargaan dari pihak lain.

5. Aktualisasi diri : Kebutuhan untuk memenuhi diri sesorang melalui memaksimumkan penggunaan kemampuan, keahlian dan potensi.

Teori maslow menggap bahwa orang mencoba memuaskan kebutuhan yang lebih mendasar sebelum mengarahkan perilaku dalam memuaskan kebutuhan yang lebih tinggi (aktualisasi diri).

Menurut Reksohadiprojo (dalam Narmodo dan Wadji 2007) menyebutkan bahwa, "motivasi adalah keadaan dalam pribadi seseorang yang mendorong keinginan individu melakukan kegiatan-kegiatan tertentu untuk mencapai tujuan organisasi". Jadi motivasi adalah faktor pengerak dalam diri seseorang yang akan mengarahkan prilaku dan prestasi kerja orang tersebut, motivasi ini di pengaruhi oleh faktor kebutuhan dan tujuan yang belum dicapai oleh seseorang.

Motivasi kerja menurut Munandar (2008) adalah suatu proses yang didalamnya kebutuhan-kebutuhan mendorong seseorang untuk melakukan serangkaian kegiatan yang mengarah ke tercapainya tujuan tertentu. Sedangkan Nawawi (2005) menjelaskan bahwa kata dasar motivasi adalah motif yang berarti dorongan, sebab, atau alasan seseorang melakukan sesuatu. Sehingga dapat disimpulkan bahwa motivasi selalu berhubungan dengan kebutuhan, keinginan, dan dorongan usaha untuk mencapai tujuan tertentu.

Menurut pendapat Robbins (2003) istilah kepuasan kerja merujuk kepada sikap umum seorang individu terhadap pekerjaan yang dilakukannya. Seseorang dengan tingkat kepuasan kerja tinggi menunjukkan sikap yang positif terhadap kerja itu sendiri sedangkan seseorang yang tidak puas dengan pekerjaannya menunjukkan sikap yang negatif terhadap pekerjaan itu. 
Keberhasilan dan kinerja seseorang dalam suatu bidang pekerjaan banyak ditentukan oleh tingkat kompetensi, profesionalisme juga komitmen terhadap bidang yang ditekuninya. Suatu komitmen organisasional menunjukkan suatu daya dari sesorang dalam mengidentifikasikan keterlibatan dalam suatu organisasi. Oleh karena itu komitmen organisasional akan menimbulkan rasa ikut memiliki (sense of belonging) bagi pekerja terhadap organisasi.

Disamping komitmen organisasi, adanya orientasi professional yang mendasari komitmen profesional nampaknya juga akan berpengaruh terhadap kepuasan kerja yang berarti bahwa karyawan hanya akan memiliki komitmen terhadap organisasi jika mereka merasa telah puas terhadap gaji, promosi, pimpinan, rekan kerja dan kondisi kerjanya. Sehingga dapat dikatakan komitmen organisasi adalah perpaduan antara sikap dan prilaku.

Komitmen organisasi menyangkut tiga sikap yaitu mengidentifikasi dengan tujuan organisasi, keterlibatan dengan tugas organisasi dan kesetiaan pada organisasi (Panggabean, 2004).

Sumber Daya Manusia merupakan salah satu pilar pertumbuhan utama Perusahaan dan Keberhasilannya dalam meningkatkan pendapatannya terutama dikontribusikan oleh pendapatan dari berbagai sektor.

PT Federal Internasional Finance (FIF) adalah perusahaan pembiayaan yang dimiliki sepenuhnya oleh Astra. Bisnis FIF awalnya difokuskan pada pembiayaan konvensional dan syariah untuk mendukung penjualan ritel sepeda motor Honda. Selanjutnya telah dikembangkan produk pembiayaan sepeda motor bekas dan Spektra sebagai kredit barang konsumsi umum, termasuk elektronik dan peralatan rumah tangga.

Salah satu prioritas utama dalam fokus kerja FIF adalah intensifikasi jaringan distribusi dengan mengutamakan sinergi dan hubungan antar fungsi dengan mitra kerja, baik dalam lingkungan jaringan bisnis Astra, Honda Sales Operation, dealer otomotif dan lainnya untuk pengembangan operasional dan produk, diantaranya produk joint financing. Inovasi produk, seperti spektra card, bertujuan untuk ekspansi dan diversifikasi basis pelanggan. FIF juga menyelenggarakan program pemasaran yang terfokus dan meningkatkan kemampuan untuk memantau perkembangan industri dengan baik sebagai dasar penyelarasan internal perusahaan dengan kondisi eksternal untuk memenangkan persaingan. Untuk menunjang seluruh upaya tersebut, pelayanan yang maksimal bagi nasabah juga menjadi prioritas utama dalam penanganan keluhan nasabah, yang dilakukan berdasarkan fokus ditingkat cabang atau departemen terkait sehingga respon dan penyelesaian dapat ditindaklanjuti dengan cepat dan tepat, umumnya dalam jangka waktu 2 × 24 jam.

FIF GROUP sepenuhnya menyadari bahwa Sumber Daya Manusia merupakan aset penting bagi Perusahaan untuk meningkatkan kinerja Perusahaan. Pengembangan Sumber Daya Manusia di FIF GROUP diarahkan pada pembentukan value culture melalui spirit team (Teamwork, Excellence, Achieving dan Moving Forward) yang menjadi landasan dari pola pikir dan aktifitas kerja yang dilaksanakan oleh insan FIF GROUP. 
Perusahaan juga melihat setiap karyawan memiliki peran dan kompetensi yang unik dan khas sehingga kami terus berupaya mengembangkan karyawan sesuai dengan karakteristik kompetensi masing-masing secara optimal. Selain program pengembangan, Perusahaan juga terus memberikan motivasi kepada seluruh insan FIF GROUP dalam bekerja. Perusahaan meyakini, dengan skema pengembangan kompetensi yang tepat serta diiringi oleh tumbuhnya motivasi dan kesadaran akan peran masing-masing bagi Perusahaan, seluruh karyawan akan dapat memberikan kontribusi kepada pertumbuhan Perusahaan secara optimal.

Skema pengembangan Sumber Daya Manusia FIF GROUP juga didasarkan pada aspek kreativitas di mana setiap individu di FIF GROUP diwajibkan untuk memiliki kreatifitas mulai dari tim dan unit kerja masing-masing untuk kemudian mengembangkan kreatifitas tersebut dalam berbagai program dan strategi kerja yang dapat membawa FIF GROUP untuk bertahan di tengah persaingan dengan perusahaan lain di industri pembiayaan.

Selain kreatifitas, perusahaan juga menekankan pentingnya komitmen untuk hadir dalam diri seluruh insan FIFG ROUP di mana komitmen merupakan aspek yang berkaitan erat dengan sistem, untuk saling bersinergi antara dealer, nasabah, karyawan serta dengan Manajemen dan Pemegang Saham. Melalui Motivasi dan Kepuasan kerja serta komitmen organisasi, perusahaan mengharapkan rangkaian produk dan layanan FIF GROUP dapat diberikan secara luas dengan nilai tambah bagi seluruh pemangku kepentingan Perusahaan.

Pada dasarnya, PT. FIF GROUP bukan saja mengharapkan karyawan yang mampu, cakap, dan terampil, tetapi yang terpenting mereka mau bekerja giat dan berkeinginan untuk mencapai hasil kerja yang optimal. Kemampuan, kecakapan, dan keterampilan karyawan tidak ada artinya bagi perusahaan, jika mereka tidak mau bekerja keras dengan mempergunakan kemampuan, kecakapan, dan keterampilan yang dimilikinya. Motivasi kerja, kepuasan kerja dan komitmen organisasi penting karena dengan motivasi kerja, kepuasan kerja dan komitmen organisasi yang memadai diharapkan setiap karyawan mau bekerja keras dan antusias untuk mencapai produktivitas kerja yang tinggi dengan didukung oleh kemampuan yang mumpuni dan berkualitas.

Dalam upaya menciptakan kinerja karyawan yang optimal pada PT. Federal Internasional Finance Cabang Maros masih terdapat banyak kendala yang dihadapi sehingga sulit untuk mencapai tujuan organisasi. Dimana Banyak fenomena-fenomena yang ditemui terkait dengan rendahya motivasi karyawan antara lain adalah kurangnya inisiatif kerja karyawan dalam melaksanakan tugas, seperti bekerja dengan penuh ketekunan jika hanya diawasi oleh pimpinan, sebagian karyawan dalam bekerja masih menggunakan cara-cara kerja lama dan tidak adanya keinginan karyawan untuk melakukan sistem kerja yang baru.

Perusahaan yang siap berkompetisi harus memiliki manajemen yang efektif, Selain faktor motivasi kerja, kepuasan kerja karyawan juga tidak kalah pentingnya didalam meningkatkan kinerja karyawan, Kepuasan kerja karyawan pada dasarnya sangat individualis dan merupakan hal yang sangat tergantung pada pribadi masing-masing karyawan. Ketidakpuasan karyawan dapat terjadi apabila pekerjaan yang dilakukan tidak sesuai dengan apa yang diperoleh dari perusahaan. Ketidakpuasan para karyawan ini menimbulkan hal-hal yang tidak diinginkan dan dapat merugikan perusahaan yang bersangkutan. Misalnya adanya 
aksi mogok kerja, kemangkiran karyawan meningkat, turunnya kinerja karyawan, dan lain-lain, yang pada akhirnya akan menurunkan kinerja perusahaan itu sendiri. Maka para pimpinan sebaiknya mengerti apa yang dibutuhkan para karyawan dan mengetahui keinginan-keinginan apa yang membuat karyawan puas dan meningkatkan kinerjanya, termasuk apa dan berapa bonus yang akan mereka terima jika target atau tujuan kerjanya tercapai. Sehingga para karyawan tidak melakukan hal-hal yang tidak sepantasnya dikerjakan.

Selain motivasi kerja dan kepuasan kerja, fenomena - fenomena yang terjadi didalam perusahaan adalah adanya keinginan karyawan berpindah keperusahaan lain menurunnya komitmen organisasi terhadap karyawan dan banyaknya karyawan berstatus kontrak padahal sudah lama bekerja diperusahaan tersebut. Selain itu karyawan merasa tidak sepenuhnya menjadi bagian dari perusahaan sehingga rasa kerja keras karyawan dalam mencapai tujuan perusahaan tidak tercapai, rendahnya kualitas kerja, meningkatnya keterlambatan kerja dan kurangnya loyalitas pada perusahaan. Disamping itu kadang karyawan merasa lelah dengan pekerjaan yang mereka terima karena usia sebagian besar karyawan masih berusia produktif maka karyawan sering berfikir untuk mencari alternatif pekerjaan lain.

Penelitian ini bertujuan untuk mengetahui seberapa besar pengaruh variabel motivasi kerja, kepuasan kerja, dan komitmen organisasi terhadap kinerja karyawan pada PT. Federal Internasional Finance Cabang Maros

\section{METODE PENELITIAN}

\section{Pendekekatan Penelitian}

Penelitian ini merupakan jenis penelitian deskriptif kuantitatif dengan pendekatan Analisa Korelasi Sederhana dan Regresi Linear Berganda untuk mengukur hubungan antar variabel. Pemilihan metode ini berdasarkan rumusan masalah, dimana peneliti ingin mengetahui pengaruh motivasi kerja, kepuasan kerja, dan komitmen organisasi terhadap kinerja karyawan.

\section{Lokasi dan waktu penelitian}

Lokasi penelitian dikantor PT. Federal Internasional Finance (FIF) cabang Maros. Waktu penelitian dilaksanakan pada bulan April 2017 sampai dengan Juni 2017.

\section{Teknik pengumpulan data}

Metode pengumpulan data dalam penelitian ini dimaksudkan untuk memperoleh data yang relevan dan akurat dengan masalah yang dibahas. Metode pengumpulan data tersebut adalah sebagai berikut :

\section{Observasi}

Observasi adalah metode dipergunakan sebagai sebagai salah satu piranti dalam pengumpulan data berdasarkan pengamatan secara langsung pengaruh motivasi kerja, kepuasan kerja dan komitmen organisasi terhadap kinerja karyawan pada PT. Federal internasioal Finance (FIF) kantor Cabang Maros.

Wawancara 
Wawancara yaitu dialog secara langsung untuk memperoleh informasi dari responden terpilih dalam menghimpun informasi yang relevan dengan penelitian yang akan diadakan di kantor PT. Federal Internasional Finance (FIF) Cabang Maros.

\section{Kuesioner}

Kuesioner adalah teknik pengumpulan data dengan mengajukan sejumlah pertanya secara tertulis yang di berikan kepada responden dengan maksud untuk memperoleh data yang akurat dan valid.

\section{Populasi dan Sampel}

Populasi merupakan jumlah keseluruhan dari objek peneltian yaitu seluruh karyawan PT. Federal Internasional Finance (FIF) Cabang Maros yang berjumlah 55 orang.

Melihat jumlah populasi pada perusahaan yang akan di teliti jumlahnya terbatas, maka penarik sampel dilakukan secara keseluruhan dengan mengunakan metode sensus. Dengan demikian, besar sampel dalam peneltian ini berjumlah 55 orang responden.

\section{Metode analisis data}

Berdasarkan tujuan yang akan dicapai dalam penelitin ini, maka data dianalisis secara deskriptif dan kuantittif. Metode analisis yang di gunakan adalah sebagai berikut :

1. Analisis secara deskriptif mengenai pengaruh motivasi kerja, kepuasan kerja dan komitmen organisasi terhadap kinerja karyawan pada PT. Federal Internasional Finance (FIF) kantor Cabang Maros.

2. Uji Validitas

Uji validitas dimaksudkan untuk mengetahui sejauh mana suatu alat pengukur (instrument) dapat mengkur apa yang diukur (Singarimbun, 1995). Pengujian validitas dilakukan dengan beberapa langkah-langkah, antara lain (Singarimbun,1995) :Mendefeniskan secara operasinal konsep yang akan diukur, Melakukan uji coba skala pengukuran dengan mengunakan responden, Mempersiapkan table jawaban dan Menghitung korelasi.

3. Reliabilitas

Reliabilitas adalah suatu indeks tentang sejauh mana suatu alat ukur dapat di percaya atau diandalkan. Jika suatu alat ukur dapat digunakan dua kali untuk mengukur gejala yang sama dan hasil pengukurannya diproses relative secara konsisten, maka alat ukur tersebut dianggap reliable. Artinya suatu alat ukur yang di gunakan konsisten dalam mengukur gejala yang sama.

4. Metode analisis regresi linear berganda menurut Hasan (2008) dengan rumus :

$Y=b_{0}+b_{1} X_{1}+b_{2} X_{2}+b_{3} X_{3}+e_{i}$

Dimana :

$$
\begin{array}{ll}
\mathrm{Y} & =\text { Kinerja } \\
\mathrm{X}_{1} & =\text { Motivasi kerja }
\end{array}
$$


Equilibrium,Vol.3, No.4(2) Hal. 687-943, Desember 2017

ISSN : 2460-7150

$$
\begin{array}{ll}
\mathrm{X}_{2} & =\text { Kepuasan kerja } \\
\mathrm{X}_{3} & =\text { Komitmen Organiasi } \\
\mathrm{B}_{1}-\mathrm{b}_{3} & =\text { Koefisien Regresi (Parameter) } \\
\mathrm{b} 0 & =\text { Konstanta (Intercept) } \\
\mathrm{e}_{\mathrm{i}} & =\text { Faktor Kesalahan }
\end{array}
$$

Selanjutnya untuk menetukan pengaruh dan tingkat signifikan digunakan $\alpha=0,05$

\begin{tabular}{|c|c|c|c|c|c|}
\hline \multirow[t]{2}{*}{ Model } & \multicolumn{2}{|c|}{$\begin{array}{l}\text { Unstandardized } \\
\text { Coefficients }\end{array}$} & \multirow{2}{*}{$\begin{array}{l}\text { Standardized } \\
\text { Coefficients } \\
\text { Beta }\end{array}$} & \multirow[t]{2}{*}{$\mathrm{T}$} & \multirow[t]{2}{*}{ Sig. } \\
\hline & $B$ & $\begin{array}{l}\text { Std. } \\
\text { Error }\end{array}$ & & & \\
\hline (Constant) & .798 & .627 & & 1.272 & .209 \\
\hline Motivasi Kerja (X1) & .339 & .122 & .334 & 2.765 & .008 \\
\hline Kepuasan Kerja (X2) & .398 & .126 & .374 & 3.161 & .003 \\
\hline $\begin{array}{l}\text { Komitmen } \text { Organisasi } \\
(\mathrm{X} 3)\end{array}$ & .070 & .088 & .099 & .795 & .430 \\
\hline
\end{tabular}
atau 5\% dapat di uji dengan mengunakan uji-F dan uji-t melalui program SPSS 22.0.

HASIL

Analisis Regresi Linear Berganda

Coefficients $^{\mathrm{a}}$

a. Dependent Variable: $Y$

Berdasarkan Tabel 13, maka dapat disusun model persamaan regresi linear berganda sebagai berikut:

$$
\begin{gathered}
Y=\propto+b_{1} X_{1}+b_{2} X_{2}+b_{3} X_{3} \\
Y=0.798+0,339 X_{1}+0,398 X_{2}+0,070 X_{3}
\end{gathered}
$$

Interpretasi dari persamaan regresi linear berganda di atas dapat diuraikan sebagai berikut : 
1. Konstanta $(\mathrm{bo})=$ diperoleh nilai 0.798 yang menyatakan bahwa besarnya kinerja karyawan pada PT. Federal Internasional Finance Cabang Maros dimana motivasi kerja, kepuasan kerja dan komitmen organisasi bernilai constant

2. Koefisien $b 1=0.339$ mempunyai arti positif yang menunjukan bahwa motivasi kerja berpengaruh positif dan signifikan terhadap kinerja karyawan pada PT. Federal Internasional Finance Cabang Maros, koefisien b1 tersebut dikarenakan nilai $\alpha=0.008$ lebih kecil dari $\alpha=0.05$ dapat dijelaskan bahwa jika ada peningkatan motivasi kerja dan variabel lainya constant, maka akan meningkatkan kinerja karyawan pada PT. Federal Internasional Finance Cabang Maros. Pengaruh variabel motivasi kerja (X1) terhadap kinerja karyawan $(Y)$ sebesar 0.339

3. Koefisien b2 $=0.398$ mempunyai arti positif yang menunjukan bahwa kepuasan kerja berpengaruh positif dan signifikan terhadap kinerja karyawan pada PT. Federal Internasional Finance Cabang Maros, koefisien b2 tersebut dikarenakan nilai $\alpha=0.003$ lebih kecil dari $\alpha=0.05$. Hal tersebut bahwa karyawan dengan tingkat kepuasan kerja tinggi maka karyawan menunjukan kinerja terbaiknya pada PT. Federal Internasional Finance Cabang Maros. Pengaruh variabel kepuasan kerja (X2) terhadap kinerja karyawan $(\mathrm{Y})$ sebesar 0.398

4. Koefisien b3 $=0.070$ mempunyai arti positif yang menunjukan bahwa komitmen organisasi berpengaruh positif dan tidak signifikan terhadap kinerja karyawan pada PT. Federal Internasional Fiance Cabang Maros, koefisien b3 tersebut dikarenakan nilai $\alpha=$ 0.430 lebih besar dari $\alpha=0.05$. Hal ini menunjukan bahwa semakin rendah komitmen organisasi yang dimiliki karyawan semakin rendah pula kinerja karyawan pada PT. Federal Internasional Finance Cabang Maros. Pengaruh variabel komitmen organisasi (X3) terhadap kinerja karyawan sebesar 0.070

Besarnya pengaruh variabel motivasi kerja, kepuasan kerja, serta komitmen organisasi terhadap kinerja karyawan dapat diketahui melalui angka beta atau standardized coefficient dari Tabel 13.

\section{PEMBAHASAN}

\section{Pengaruh Motivasi Kerja terhadap Kinerja Karyawan}

Motivasi merupakan dorongan terhadap serangkaian proses prilaku manusia pada pencapaian tujuan (Wibowo, 2010:379). Motivasi dalam manajemen ditunjukan pada sumber daya manusia umumnya dan bawahan khususnya. Motivasi mempersoalkan bagaimana cara mengarahkan daya dan potensi bawahan, agar mau bekerja sama secara produktif berhasil mencapai dan mewujudkan tujuan yang telah ditentukan. Pentingnya motivasi karena menyebabkan, menyalurkan dan mendukung prilaku manusia, supaya mau bekerja giat dan antusias mencapai hasil yang optimal.

Hasil Frekuensi dan presentase tanggapan responden karyawan PT. Federal Internasional Finance Cabang Maros mengenai motivasi kerja menunjukan bahwa responden memberi nilai yang efektif terlihat dari nilai total rata-rata sebesar $4.08 \%$. Hal ini berarti motivasi kerja sangat penting untuk mendorong para karyawan bekerja lebih baik lagi, indikator yang dominan membentuk variabel motivasi kerja adalah indikator prestasi dengan nilai rata-rata $4.29 \%$ yaitu untuk menjadi karyawan yang berprestasi diperlukan 
kerja keras. Artinya prestasi merupakan hal yang diharapkan baik oleh karyawan maupun organisasi. Jika seorang karyawan memiliki kemampuan yang lebih dari harapan organisasi maka perusahaan atau organisasi harus memberikan sesuatu pencapaian prestasi tersebut, misalnya dalam bentuk promosi. Sedangkan indikator pendukung motivasi kerja untuk karyawan adalah minat pada pekerjaan dengan nilai rata-rata $4.16 \%$ yang menyatakan bahwa karyawan menikmati setiap pekerjaan yang diberikan dari pimpinanan. Hal ini menunjukan indikator-indikator tersebut merupakan kebutuhan utama, oleh karena itu jika terpenuhi dapat menjadi pendorong yang kuat bagi karyawan PT. Federal Internasional Finance Cabang Maros untuk bekerja lebih baik dan maksimal.

Dari hasil penelitian diketahui adanya pengaruh positif dan signifikan motivasi kerja terhadap kinerja karyawan PT. Federal Internasional Finance Cabang Maros, indikator yang digunakan untuk mengukur motivasi adalah prestasi, pengakuan, minat pada pekerjaan, kemajuan dan tangung jawab. Hal ini dibuktikan dengan nilai thitung sebesar 2.765 dengan nilai signifikansi sebesar 0.008 lebih kecil dari $\alpha=0.05$. Nilai koefisien sebesar 0.339 . Artinya semakin baik motivasi yang karyawan miliki maka peningkatan kinerja karyawan PT. Federal Internasional Finance Cabang Maros semakin meningkat.

Dalam aktivitas kerja karyawan juga memotivasi diri dengan menunjukan motivasi prestasi dengan mengembangkan atau memelihara dedikasi kerja untuk melaksanakan aktivitas kerja wujud dedikasi kerja yaitu karyawan memiliki solidaritas untuk menjalankan tugas yang diberikan oleh pimpinan dengan sunguh-sunguh untuk mewujudkan pencapaian kinerja. Tidak dapat dipungkiri bahwa setiap orang dalam menghadapi dinamika kerja ingin dikatakan berprestasi. Adanya motivasi untuk berprestasi dalam melaksanakan pekerjaan akan memberikan pengaruh terhadap kinerja karyawan PT. Federal Internasional Finance Cabang Maros.

Hal ini menunjukan bahwa upaya memberikan motivasi kerja kepada setiap karyawan baik secara individu maupun secara kolektif untuk menentukan hasil kerja yang dicapai. Peningkatan motivasi tersebut juga dapat dilakukan melalui pemberian penghargaan yang merupakan bentuk penilaian tertinggi atas sikap dan perilaku kerja yang disenangi oleh seorang karyawan pada intinya adalah wujud pengakuan/pujian yang mana setiap manusia didalam pengembangan potensi pada dirinya membutuhkan adanya pengakuan/pujian. Pengakuan menjadi motvasi dalam dirinya untuk senantiasa menjalankan tugas pokok dan fungsinya secara optimal untuk mendapatkan apresiasi pengakuan baik pengakuan dari pimpinan, pengakuan dari teman menjadi motivasi yang memberikan pengaruh terhadap kinerja karyawan PT. Federal Internasional Finance Cabang Maros.

Dari hasil tersebut juga diketahui terdapat hubungan positif antara motivasi kerja terhadap kinerja karyawan PT. Federal Internasional Finance Cabang Maros dalam arti kata apabila motivasi kerja meningkat maka kinerja karyawan PT. Federal Internasional Finance Cabang Maros juga meningkat. Hal ini sesuai dengan pendapat Munandar (2008) yang menyatakan ada hubungan positif antara motivasi dan kinerja dengan pencapaian prestasi, artinya manejer yang mempunyai motivasi prestasi yang tinggi cendrung mempunyai kinerja 
tinggi sebaliknya mereka yang mempunyai kinerja rendah dimungkinkan karena motivasinya rendah.

\section{Pengaruh Kepuasan Kerja terhadap Kinerja Karyawan}

Kepuasan kerja merupakan salah satu faktor yang sangat penting untuk mendapatkan hasil kerja yang optimal. Ketika seseorang merasakan kepuasan dalam bekerja tentunya ia akan berupaya semaksimal mungkin dengan segenap kemampuan yang dimilikinya untuk menyelesaikan tugasnya. Dengan demikian produktivitas akan meningkat secara optimal. Kepuasan merujuk pada sikap umum seseorang individu terhadap pekerjaannya.

Hasil Frekuensi dan presentase tanggapan responden karyawan PT. Federal Internasional Finance Cabang Maros mengenai kepuasan kerja menunjukan bahwa responden memberi nilai yang sangat efektif terlihat dari total rata-rata sebesar $4.14 \%$. Hal ini berarti kepuasan kerja penting untuk meningkatkan karyawan dalam menyelesaikan pekerjaan perusahaan, indikator yang dominan membentuk variabel kepuasan kerja dan indikator pendukung kepuasan kerja untuk karyawan adalah indikator rekan kerja dengan nilai rata-rata $4.16 \%$ dan $4.14 \%$ yang menyatakan karyawan selalu membina hubungan baik dengan semua rekan kerja dan setiap karyawan memiliki rekan kerja yang menyenangkan. Artinya bahwa kebutuhan dasar manusia untuk melakukan hubungan sosial akan terpenuhi dengan adanya rekan kerja yang mendukung karyawan. Hal ini menujukan bahwa rekan kerja memiliki peran yang sangat penting dalam hubungan bersosialisasi sesama karyawan untuk kemajuan perusahaan.

Dari hasil penelitian diketahui adanya pengaruh positif dan signifikan Kepuasan kerja terhadap kinerja karyawan PT. Federal Internasional Finance Cabang Maros. Indikator yang digunakan untuk mengukur kepuasan kerja adalah pekerjaan itu sendiri, gaji, pengawasan dan rekan kerja. Hal ini dibuktikan dengan nilai t hitung sebesar 3.161 dengan nilai signifikansi sebesar 0.003 lebih kecil dari $\alpha=0.05$. Artinya karyawan dengan tingkat kepuasan kerja tinggi menunjukan sikap terhadap pekerjaan itu dan semakin tinggi kepuasan kinerja karyawan maka karyawan menunjukan kinerja terbaiknya. Keadaan ini menunjukan bahwa kepuasa kerja yang dirasakan oleh karyawan berdasarkan keberhasilan dalam melaksanakan tugas-tugas yang diberikan tepat waktu dan sesuai harapan pimpinan serta mendapat apresiasi dari pimpinan, sehingga secara tidak langsung memberikan kontribusi terhadap kinerjanya.

Dari hasil penelitian tersebut juga diketahui terdapat hubungan positif antara kepuasan kerja karyawan terhadap kinerja karyawan PT. Federal Internasonal Finance Cabang Maros, dalam arti kata jika kepuasan kerja meningkat maka kinerja karyawan meningkat. Hal ini sesuai dengan teori yang dikemukakan oleh Winardi (2001:137) Kepuasan kerja merupakan suatu sikap positif yang menyangkut penyesuain diri yang sehat dari dalam diri karyawan terhadap kondisi dan situasi kerja, termasuk didalamnya upah, kondisi sosial, kondisi fisik dan kondisi psikologis. Apabila perusahaan senantiasa melaksanakan system karir dan kompensasinya dengan baik, adanya hubungan yang baik 
antara rekan kerja, sikap atasan yang selalu memotivasi, serta lingkungan kerja fisik yang kondusif mengakibatkan karyawan menjadi merasa aman dan nyaman dalam bekerja. Dampaknya adalah karyawan bekerja dengan sebaik-baiknya dan selalu memberikan pelayanan terbaiknya kepada pelanggan, dalam hal ini nasabah PT. Federal Internasional Finance Cabang Maros. Hal tersebut menunjukan kinerja karyawan tersebut tinggi.

Hal ini sesuai dengan pendapat Luthans (2006 : 246) yang mengatakan Metaanalisis yang lebih rumit dilakukan oleh Tim Jugde dan rekannya pada 312 sampel dengan kombinasi $N 54,417$ menemukan korelasi sebenarnya menjadi 0,30. Dengan demikian hasil analisis ini menunjukkan hubungan yang jauh lebih kuat antara kepuasan kerja dan kinerja karyawan.

Timmreck (2001) juga mengatakan bahwa faktor yang dapat mempengaruhi kinerja adalah kepuasan kerja karyawan sebagaimana didefinisikan berikut ini, kepuasan kerja karyawan adalah terpenuhi atau tidaknya keinginan mereka terhadap pekerjaan itu sendiri.

Hasil penelitian ini mendukung penelitian yang dilakukan oleh Purwanto dan wahyudin (2011), yang mengkaji tentang pengaruh faktor-faktor kepuasan kerja terhadap kinerja karyawan. Penelitian tersebut memperoleh hasil bahwa faktor - faktor kepuasan kerja yang meliputi gaji, kepemimpinan, sikap dan rekan kerja memiliki pengaruh positif dan signifikan terhadap kinerja karyawan. Pada penelitian ini juga diperoleh hasil bahwa sikap rekan sekerja merupakan faktor yang berpengaruh dominan terhadap kinerja karyawan.

Penelitian lainnya yang memperoleh hasil serupa dengan penelitian yang dilakukan oleh Kusuma Adi Rahrajo (2016) yang berjudul Pengaruh motivasi, Kepuasan kerja dan komitmen organisasi terhadap kinerja karyawan pada PT. Sumber Urip Sejati di Surabaya yang menunjukan bahwa Kepuasan kerja berpengaruh positif dan signifikan terhadap Kinerja Karyawan. Jadi semakin terpuaskan karyawan, maka karyawan semakin menunjukan kinerja terbaiknya. Sebaliknya jika karyawan tidak merasa puas dalam bekerja, maka dalam diri karyawan timbul rasa malas sehingga berdampak pada menurunnya kinerja. Hal ini sesuai dengan teori yang dikemukakan oleh Robbins (2006) mengenai dampak kepuasan kerja terhadap kinerja karyawan. Robbins menyatakan bahwa karyawan yang puas berkemungkinan lebih besar untuk berbicara positif tentang organisasi, membantu yang lain dan berbuat kinerja pekerjaan mereka melampaui perkiraan normal. Dengan demikian, hasil penelitian ini sesuai teori yang digunakan sebagai acuan dan sesuai pula hasil - hasil penelitian yang relevan.

\section{Pengaruh Komitmen Organisasi terhadap kinerja karyawan}

Tingkat komitmen baik komitmen perusahaan terhadap karyawan maupun karyawan terhadap perusahaan sangat diperlukan karena melalui komitmen-komitmen tersebut terciptanya iklim kerja yang professional. Individu yang terpuaskan dengan pekerjaannya cenderung untuk memenuhi komitmen terhadap organisasi, sehingga munculnya loyalitas karyawan terhadap organisasi, yang akhirnya menyebabkan karyawan tersebut memiliki rasa ketergantungan dan tanggung jawab terhadap organisasi. Individu yang memiliki komitmen organisasi rendah cenderung untuk melakukan cara yang dapat menganggu kinerja organisasi seperti turnover yang tinggi, keterlambatan dalam bekerja, keluhan dan 
bahkan mogok kerja.

Hasil Frekuensi dan presentase tanggapan responden karyawan PT. Federal Internasional Finance Cabang Maros mengenai komitmen organisasi menunjukan bahwa responden memberi nilai kurang efektif terlihat dari nilai total rata-rata sebesar $4.16 \%$. Hal ini menunjukan bahwa komitmen organisasi sangat rendah yang berdampak pada turunnya kinerja karyawan.

Dari hasil penelitian diketahui adanya pengaruh positif dan tidak signifikan komitmen organisasi terhadap kinerja karyawan PT. Federal Internasional Finance Cabang Maros. Indikator yang digunakan untuk mengukur Komitmen organisasi 1. Komitmen afektif terdiri dari : Karyawan merasa bahagia bekerja dalam organisasi, karyawan menunujukan rasa memiliki. 2 Komitmen berkelanjutan terdiri dari : Karyawan merasa tidak memiliki alternatif kerja ditempat lain yang lebih manarik, Karyawan merasa rugi apa bila meningalkan perusahaan. 3. Komitmen normatif terdiri dari : Karyawan merasa memiliki kewajiban untuk setia pada perusahaan, Karyawan telah terikat kontrak kerja dengan perusahaan sehingga harus menyelesaikan kontraknya tersebut, Hal ini dibuktikan dengan nilai t hitung sebesar 0.795 dengan nilai signifikansi sebesar 0.430 lebih besar dari $\alpha=0.05$. Artinya semakin rendah komitmen yang dimiliki karyawan semakin rendah pula kinerja karyawan terhadap perusahaan PT. Federal Internasional Finance Cabang Maros.

Hal ini sesuai dengan temuan Somers dan Birnbaum (1998) dalam penelitiannya tentang Hubungan kerja dan komitmen terhadap kinerja bahwa komitmen organisasional (affective dan continuance) tidak berpengaruh terhadap kinerja. Ditinjau dari segi organisasi menurut Steers dan Porter (1991), karyawan yang berkomitmen rendah berdampak pada tingginya absensi, meningkatnya keterlambatan kerja, dan kurangnya intensitas untuk bertahan sebagai karyawan di organisasi tersebut, rendahnya kualitas kerja, dan kurangnya loyalitas pada perusahaan.

Hasil penelitian ini sejalan dengan penelitian sebelumnya yang di lakukan oleh Engar, Dwi Jatmiko (2015) yang berjudul Pengaruh motivasi dan komitmen organisasi terhadap kinerja karyawan (Studi pada kompartemen pabrik II PT. Petrokimia Gresik) yang menunjukan bahwa Komitmen organisasi berpengaruh negatif dan tidak signifikan terhadap Kinerja karyawan.

Komitmen organisasi dalam diri karyawan harus ditingkatkan untuk manfaatnya lebih terasa dan kinerja karyawan terus meningkat dan sikap yang dimilki karyawan untuk tetap loyal terhadap perusahaan dan bersedia untuk tetap tingal dengan sebaik mungkin demi tercapainya tujuan organisasi. Sesuai dengan teori dari ahli yang telah dijabarkan oleh penulis bahwa jika karyawan memiliki komitmen organisasi yang tinggi maka karyawan tetap tinggal dalam organisasi dan terus meningkatkan kinerjanya.

\section{Variabel Dominan Berpengaruh Terhadap Kinerja Karyawan}

Berdasarkan hasil uji stastistik terhadap ketiga variabel independen yaitu Motivasi kerja, Kepuasan kerja dan Komitmen organisasi terhadap Kinerja Karyawan, terlihat bahwa variabel Kepuasan kerja (X2) memiliki angka Unstandardized Coefficients sebesar 0.398 
dibandingkan variabel Motivasi Kerja (X1) sebesar 0.339 dan variabel Komitmen organisasi (X3) sebesar 0.070. Hal ini menunjukan bahwa Kepuasan kerja memiliki pengaruh yang dominan terhadap kinerja karyawan pada PT. Federal Internasional Finance Cabang Maros.

Dibuktikan dari hasil uji statistik terhadap variabel Motivasi kerja (X1), Kepuasan kerja (X2) dan Komitmen organisasi (X3), diperoleh hasil bahwa variabel yang berpengaruh positif dan signifikan terhadap kinerja karyawan yaitu variabel Motivasi kerja, variabel Kepuasan kerja dan variabel komitmen organisasi. Variabel Motivasi kerja terhadap kinerja karyawan diperoleh nilai t hitung sebesar 2.765 dengan tingkat signifikan 0.008 yang lebih kecil dari tingkat signifikan (a) 0,05. Sedangkan Komitmen organisasi terhadap kinerja karyawan diperoleh nilai t hitung sebesar 0.795 dengan tingkat signifikan 0.430 yang lebih besar dari tingkat signifikan (a) 0,05 dan Kepuasan kerja terhadap kinerja karyawan diperoleh nilai t hitung sebesar 3.161 dengan tingkat signifikan 0.003 yang lebih kecil dari tingkat signifikan (a) 0,05. Hal ini menujukan bahwa variabel Kepuasan kerja memiliki nilai $t$ hitung 3.161 lebih besar dibandingkan dengan variabel motivasi kerja dengan nilai t hitung 2.765, artinya yang paling dominan berpengaruh terhadap kinerja karyawan pada PT. Federal Internasional Finance Cabang Maros adalah variabel Kepuasan kerja.

Karyawan PT. Federal Internasional Finance Cabang Maros yang merasa puas lebih terlibat dalam organisasi yang dapat meningkatkan produktifitas. Dengan kepuasan kerja yang diperoleh diharapkan kinerja karyawan yang tinggi dapat dicapai para karyawan. Tanpa adanya kepuasan kerja karyawan PT. Federal Internasional Finance Cabang Maros dalam bekerja, maka akibatnya kinerja karyawan menjadi rendah sehingga tujuan perusahaan secara maksimal tidak tercapai.

Uraian diatas menunjukan bahwa variabel Kepuasan kerja mempunyai peranan yang dominan dalam meningkatkan Kinerja karyawan pada PT. Federal Internasonal Finance Cabang Maros. Hal ini menyebabkan karyawan mampu melaksanakan kegiatan dengan baik sehingga dicapai suatu hasil yang maksimal apabila memiliki Kepuasan kerja yang baik dari dalam maupun dari luar diri karyawan itu sendiri.

\section{KESIMPULAN DAN SARAN}

\section{A. Kesimpulan}

Berdasarkan hasil penelitian di atas, maka di tarik simpulan sebagai berikut :

1. Motivasi kerja berpengaruh positif dan signifikan terhadap kinerja karyawan pada PT.Federal Internasional Finance Cabang Maros. Hal ini mengindikasikan bahwa motivasi kerja menjadi sangat berguna untuk membantu peningkatan kinerja karyawan pada PT. Federal Internasional Finance Cabang Maros.

2. Kepuasan kerja berpengaruh positif dan signifikan terhadap kinerja karyawan PT. Federal Internasional Finance Cabang Maros. Hal ini mengindikasikan bahwa peningkatan kinerja karyawan dipengaruhi oleh kepuasan kerja.

3. Komitmen organisasi berpengaruh positif dan tidak signifikan terhadap kinerja karyawan PT. Federal Internasional Finance Cabang Maros. Hal ini menunjukan bahwa jika komitmen organisasi menurun maka kinerja karyawan juga akan menurun.

4. Variabel kepuasan kerja lebih dominan mempengaruhi jika dibandingkan dengan variabel motivasi kerja dan komitmen organisasi dalam meningkatkan kinerja karyawan PT. Federal 
Internasional Finance Cabang Maros. Hal ini mengindikasikan bahwa variabel kepuasan kerja lebih berperan dalam menentukan peningkatan kinerja karyawan PT. Federal Internasional Finance Cabang Maros.

\section{B. Saran}

Berdasarkan kesimpulan di atas maka penulis memberikan beberapa saran sebagai berikut:

1. Motivasi dalam penelitian ini diukur dengan menggunakan prestasi, pengakuan, minat pada pekerjaan dan kemajuan. Hal ini harus lebih ditingkatkan lagi PT. Federal Internasional Finance Cabang Maros sehingga untuk mengoptimalkan kinerja karyawan perlu kebijakan yang mengakomodasi semua pihak dalam rangka memberikan Motivasi karyawan, misalnya dengan memberikan motivasi yang memadai, adanya pengakuan dan penghargaan dari atasan sehingga akan berpengaruh terhadap kinerja karyawan PT. Federal Internasional Finance Cabang Maros.

2. Kepuasan kerja dalam penelitian ini diukur dengan menggunakan pekerjaan itu sendiri, gaji, pengawasan dan rekan kerja. Perlu adanya kebijakan yang benar-benar memperhatikan kinerja karyawan. Perusahaan harus memperhatikan kepuasan kerja karyawan terutama gaji pokok dan pengawasan pimpinan terhadap karyawan. Kepuasan kerja karyawan perlu dipertahankan dan ditingkatkan agar dapat memberikan pengaruh yang maksimal dalam meningkatkan mutu dan kualitas kinerja karyawan pada PT. Federal Internasional Finance Cabang Maros.

3. Komitmen organisasi memiliki pengaruh yang positif dan tidak signifikan terhadap Kinerja karyawan pada PT. Federal Internasional Finance Cabang Maros, sehingga saran yang ditujukan pada pimpinan bahwa dalam meningkatkan kinerja karyawan dengan cara memperhatikan absensi yang membuat keterlambatan karyawan bekerja, lebih ditingkatkan lagi kualitas karyawan dan menigkatkan loyalitas karyawan pada perusahaan.

4. Dari hasil penelitian yang dilakukan peneliti bahwa variabel yang paling dominan dalam mempengaruhi kinerja karyawan yaitu kepuasan kerja. Dukungan dari pimpinan sangat mempengaruhi kepuasan kerja yang dirasakan oleh karyawan. Dukungan lebih yang diberikan oleh pimpinan dapat membuat karyawan merasa nyaman dalam bekerja dan karyawan diberi tanggung jawab lebih sehingga karyawan PT. Federal Internasional Finance Cabang Maros dapat memaksimalkan kemampuannya untuk bekerja lebih baik.

5. Penelitian ini dapat menjadi referensi bagi peneliti yang akan datang yang berminat meneliti mengenai pengaruh motivasi kerja, kepuasan kerja dan komitmen organisasi terhadap kinerja karyawan pada obyek penelitian yang lain.

\section{DAFTAR PUSTAKA}

Candika Satriya Ginanjar, 2016. Pengaruh Motivasi kerja, Kepuasan Kerja, dan Komitmen Organiasi Terhadap Kinerja Karyawan Pada PT.Federal Internasional Finance(FIF).Kantor Cabang Walleri. Fakultas Ekonomi dan Bisnis. Universitas Dian Nuswantoro Semarang. 
Enggar Dwi Jatmiko, 2015 Pengaruh Motivasi kerja dan Komitmen Organisasi Terhadap Kinerja Karyawan (Studi pada kompartemen pabrik II PT.Petrokimia Gresik) Jurnal Administrasi Bisnis (JAB)/Vol. 21 No. 1 April 2015/ Fakultas Ilmu Administrasi Universitas Brawijaya Malang

Eduard. Y. Tamaela dan Herman Surijadi, 2014 Pengaruh Kepuasan Kerja, Motivasi Kerja dan Komitmen Organisasional Terhadap Kinerja Pegawai SKPD Di Kabupaten Jayapura Volume 2 No 3 Juli

Gibson, Ivancevich and Donnelly. 2001. Organisasi; Prilaku, Struktur, Proses. Jilid 2. Edisi Kedua, Jakarta: Binarupa Aksara.

Ghozali Imam, 2006, Aplikasi Analisis Multivariate dengan Program SPSS. Universitas Diponegoro

Gomes Faustino Cardoso. 2003. Manajemen Sumber Daya Manusia, Andi Offset.

Husnan, Suad. 2002. Manajemen Personalia, BPFE. Yogyakarta, Yogyakarta

Hasan, M. Iqbal. 2008. Pokok-pokok Materi Statistik 1 (Statistik Deskriptif), Jakarta: Bumi Aksara.

Handoko, T. Hani. 2002. Manajemen Personalia dan Sumber Daya Manusia. BPFEYogyakarta, Yogyakarta

Hasibuan, Malayu. 2009. Manajemen Personalia. Yogyakarta : BPFE.

.2010. Organisasi \& Motivasi, PT.Bumi aksara, Jakarta

llyas Yaslis, 2005, Kinerja, Teori dan Penelitian. Liberty: Yogyakrta.

John, M.C. dan Taylor, J.W. 1999. Leadership Style, School Climate, and the Institutional Commitment of Teachers. International Forum, Vol.2, No. 1, pp. 25-57.

Kusuma Adi Raharjo, 2016. Pengaruh Motivasi, Kepuasan kerja dan Komitmen organisasi Terhadap Kinerja Karyawan Pada PT,Sumber Urip Sejati di Surabaya, Volume 14, No.2. Januari. STIE Mahardhika Surabaya

Luthans Fred, 2006, Perilaku Organisasi ,edisi Sepuluh, Penerbit ANDI. Yogyakarta

Mangkunegara, Anwar Prabu 2001, Manajeman Sumber Daya Manusia Perusahaan, PT.Remaja Rosdakarya, Bandung.

Rosdakarya, Bandung

2005, Manajemen Sumber Daya Manusia, PT.Remaja

Marihot Tua Efendi Hariadja, 2002, Manajemen Sumber Daya Manusia. PT.Bumi Aksara, Jakarta 
Mathis, R.L dan Jackson. 2011. Human Resource Management. Jakarta : Salemba Empat.

Meyer, P. John dan Allen, J. Natalie. 1991. A Three Component Conceptualization of Organizational Commitment. Human Resources Management Review, Vol. 1, No. 1, pp. 61-89.

Maslow, A, 1984, Human Motivation, Cambridge University Press.

Munandar, 2008, Manajemen Personalia, Penerbit ANDI, Yogyakarta

Nawawi, Hadari. (2005), Manajemen Sumber Daya Manusia Untuk Bisnis Yang Kompetitif, Cetakan Ke-4, Gajah Mada Univercity Press, Yogyakarta

Panggabean, Sibarani. 2004. Komitmen Organisasi sebagai Mediator Variabel Bagi Pengaruh Kepuasan Kerja Terhadap Keinginan Untuk Pindah Kerja. Jurnal Bisnis dan Akuntansi, Vol. 6, No 1 april 2004. Jakarta: Universitas Tri Sakti.

Program Pascasarjana Universita Muslim Indonesia.2016. Pedoman Penulisan Tesis dan Disertasi.UMI Makassar.

Rachmawati Ika Kusdyah, 2008, Manajemen Sumber Daya Manusia Perusahaan, Penerbit ANDI. Yogyakarta

Purwanto dan Wahyudi, 2011. Pengaruh Faktor Kepuasan Kerja Terhadap Kinerja Karyawan Pusat Pendidikan Komputer Akuntansi IMKA di Surakarta. Program Pascasarjana Universitas Muhamadiyah Surakarta

Rivai, Veithzal, 2004, Manajemen Sumber Daya Manusia untuk Perusahaan, Raja Grafindo Persada, Jakarta . 2006. Manajemen Sumber Daya Manusia Untuk Perusahaan. Jakarta : PT.Raja Grafindo Persada.

Robbins, S dan Judge, T.A. 2008. Perilaku Organisasi. Jakarta : Salemba Empat.

Robbins, Stephen. 2003. Organizational Behavior. Edisi Kedelapan, Versi Bahasa Indonesia. Jakarta. Bhuana IImu Populer.

.2006, Perilaku Organisasi, Jilid 1 dan 2, Prehallindo, Jakarta.

Robert L. Mathias, John H. Jackson, 2006, Human Resource Management, Salemba Empat, Jakarta.

Spector, P.E. 1997. Job Satisfaction. USA : SAGE Publications, Inc.

Siagian P Sondang, 2001, Manajemen Sumber Daya Manusia, PT.Bima Aksara,Jakarta

Steers, Richard M dan Lyman W. Porter. 1991. Motivation and Work Behavior. Fifth Edition. Mc. Graw-Hill Edition. 
Equilibrium,Vol.3, No.4(2) Hal. 687-943, Desember 2017

ISSN : 2460-7150

Sopiah, 2008, Perilaku Organisasi, Penerbit ANDI. Yogyakarta

Singarimbun, Masri. 1995. Metode Penelitian Survei. LP3S, Jakarta

Somer, M.J. dan Birnbaum, Dee. 1998. Work-Related Commitmen and Job Performance; It's Also The Nature of The Performance That Counts. Jurnal of Organizational Behavior, (19) : 621-634

Sedarmayanti, 2001. Sumber Daya Manusia dan Produktivitas Kerja, Cetakan Kedua, Maju mundur, Bandung

Suwatno, H dan Priansa, D.J. 2011. Manajemen SDM dalam Organisasi Publik dan Bisnis. Bandung : Alfabeta.

Suwardi, Joko Utomo. 2011. Pengaruh Motivasi Kerja, Kepuasan Kerja, dan Komitmen organisasional Terhadap Kinerja Pegawai ( Studi pada pegawai setda kabupaten pati ).Fakultas Ekonomi Universitas Muria Kudus.

Timmreck, Thomas. 2001. Epidemologi: Suatu pengantar Ed, 2. Penerbit buku Kedokteran EGC. Jakarta

Umar, Husein. 2002. Riset Sumber Daya Manusia, Jakarta, Gramedia Pustaka Utama.

Wibowo, 2010, manajemen Kinerja, Rajawali Pers, Jakarta.

Winardi, 2004, Manajemen Perilaku Organisasi, Kencana, Jakarta

Waluyo Minto, 2009, Psikologi Teknik Industri, Graha IImu, Yogyakarta

Wirawan, 2009, Evaluasi Kinerja Sumber Daya Manusia, Salemba Empat. Jakarta

Wadji Farid, Narmodo Hermowo. 2007. Pengaruh Motivasi dan Disiplin Terhadap Kinerja Pegawai Badan Kepegawaian Daerah Kabupaten Wonogiri. Yogyakarta : Gadjah Mada University. 